\title{
Local Dermonecrosis with Generalized Urticaria Probably Due to Loxosceles rufescens Bite
}

\author{
Ioannis Alexandros Charitos ${ }^{1}$, Leonardo Pennisi ${ }^{1}$, Anna Lepore ${ }^{1}$, Luigi Santacroce ${ }^{2 *}$ \\ ${ }^{1}$ Department Emergency/Urgent, National Poison Center, Azienda Ospedaliera Universitaria OO.RR. of Foggia, Foggia, Italy; \\ ${ }^{2}$ Ionian Department, Microbiology and Virology Lab Unit, Policlinico University Hospital of Bari, Bari, Italy
}

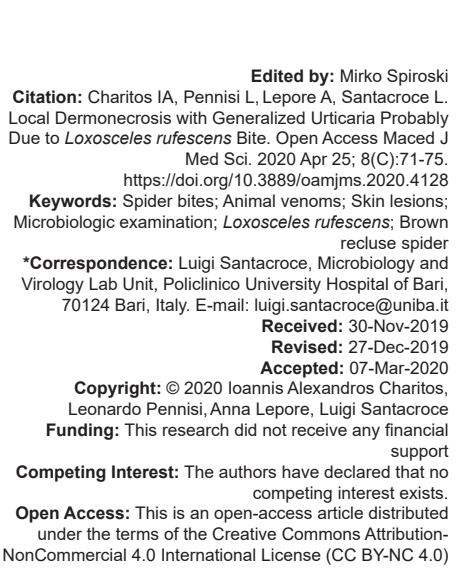

\section{ABSTRACT}

BACKGROUND: The spiders of the Loxosceles genus, commonly denoted as "brown spiders" or "Mediterranean recluse" or "brown recluse," belong to the spider family Sicariidae, suborder Labidognatha, order Araneida, class Arachnida, and phylum Arthropoda. This spider is widespread in Africa and South/Central America, but it is also distributed in North America, in the West Indies, in the Mediterranean Europe, and in China.

CASE REPORT: Here, we report the case of a severe dermonecrotic loxoscelism identified in Southern Italy, probably due to the bite of Loxosceles rufescens. The patient was a women admitted at hospital ER because of a little skin erythema that evolved toward a severe necrosis and ulceration within 20 days. After clinical and laboratory data excluded other local and systemic diseases, she was treated with a systemic and local therapy using corticosteroids and antibiotics with the diagnosis of loxoscelism. The healing from the local skin lesion occurred within 2 months, but the local pain, weakness, and discomfort lasted for a long time.

CONCLUSION: It is the fisrt time that a possible case of systemic loxoscelism with skin generalized urticaria is reported in Italy.

\section{Introduction}

Nearly 45,000 species of spiders have been described worldwide; approximately 200 species are actually considered dangerous to humans [1]. The spiders of the Loxosceles genus, commonly denoted as "brown spiders" or "Mediterranean recluse" or "brown recluse," belong to the spider family Sicariidae, suborder Labidognatha, order Araneida, class Arachnida, and phylum Arthropoda. This spider is widespread in Africa and South/Central America, but it is also distributed in North America, in the West Indies, in the Mediterranean Europe, and in China [2]. All spiders in Loxosceles genus have a violin ore fiddle marking on their back surface (Figure 1). Loxosceles rufescens is considered a highly venomous spider and the most dangerous to humans: when it pierces its prey with the fang, it squeezes out the venom, injecting the skin with it as tool for defense when it is accidentally trampled or victim of predation [3], [4]. Although most Mediterranean recluse spider bites do not cause dangerous and systemic symptoms, just dermonecrotic skin lesions, severe reactions can occur, known as "loxoscelism."

Diagnosis of Loxosceles spider's byte is often difficult for several reasons: Mainly because it is not possible to identify the spider when the bite happens silently; in fact, humans are bitten usually occur when the spider is inadvertently pressed against the skin by getting trapped in bed lines or clothing; in addition, the bite is frequently painless, hence, the patient is often unaware of it [5]; this delay between the silent bite and the time of a medical examination makes the diagnosis difficult and the treatment less effective; furthermore, the necrotic skin lesion is not always the typical one and it can be confused with an unapparent traumatic skin lesion. Moreover, at a first moment, the bite site is not painful; a mild to severe pain often begins $2-8$ hours after the bite. On the skin, a small puncture wound may appear, associated with transient erythema, itching and swelling, and mild to severe tenderness. Blebs or blisters usually appear in 12-24 hours, sometimes becoming hemorrhagic and surrounded by a halo of ischemic tissue [5], [6], [7], [8], [9]. The spider's venom contains lots of proteolytic toxins to degrade the extracellular matrix components, such as fibrinogen, fibronectin, entactin, and heparin sulfate proteoglycan and to disrupt basement membrane structures, thereby causing local dermonecrosis, inflammation, hemorrhage, gravitational spreading, disseminated intravascular coagulation (DIC), and renal failure. The activity of hydrolytic enzymes "sphingomyelinase D," 
one of the enzymes identified in its the venom, is the responsible agent for hemorrhagic and necrotic lesions. Fortunately, this species injects its venom only in $40 \%$ of its bites [10], [11] (Figure 2).

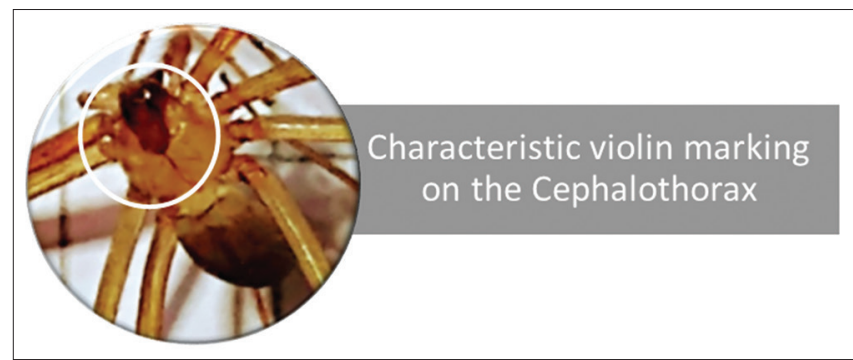

Figure 1: Loxosceles rufescens (photo by authors)

Systemic effects are less common (about $10 \%$ of cases), but may be severe or even fatal in some patients; they include nausea, vomiting, chills, fever, myalgia, generalized urticaria or purpuric rash, morbilliform rash, hemolytic anemia, disseminated intravascular coagulation, acute renal failure, shock, coma, and death [7]. There is no diagnostic test available to quickly help the physician make a diagnostic or therapeutic decision, but a rapid diagnosis is crucial for satisfactory treatment [7], [12]. In the present paper, a case, which we presumed to be due to the bite of Loxosceles rufescens, is evaluated in the light of literature [13], [14], [15], [16], [17], [18], [19], [20], [21].

We report the history of a Caucasian 48 years old woman which was at work when started to develop a severe itch on the inner side of her right thigh, but she did not consider it important. She had no idea how she got this injury, she was completely unaware that she had been bitten. Before she left for work, she slept in her house with open windows and just with light bed sheets. Two hours later, she noticed an erythematous area on her right thigh. She was not suffering from any disease and she was not taking any prescribed medications. Next day, she decided to ask the physician how to treat the skin lesion, but also because she developed a strong sense of heaviness and tension in the leg which quickly became a real excruciating pain before the onset of claudication. Her physician prescribed Bentelan tablets (Betamethasone 21-sodium phosphate) and Clavulin tablets (amoxicillin and clavulanic acid) to treat it. She went to the drugstore in order to buy an antihistaminic and a topical unguent: The pharmacist gave to her "Allerin," an homeopathic medicinal remedy for allergies (ingredients: Nux vomica, apis mell, pollen, histaminum, Lufah operculata, sabadilla, ammonium carb, allium cepa, euphrasia, and neutral globules) and "Gentalyn beta" which is a topical unguent containing betamethasone $0,1 \%$ and gentamicin $0,1 \%$. After few hours, the pain in the leg increased a lot, becoming insufferable and continuous. The day after (after $48 \mathrm{~h}$ from the alleged bite of the spider), a gray plaque appeared in the area previously erythematous (Figure 2a). She felt extreme pain with allodynia, which is pain from non-painful stimuli, such as the bed sheets contact with the skin. The skin plaque progressed to an eschar, turning black, and then it dropped off leaving a wide ulcer within 20 days, surrounded by a halo of hemorrhagic and ischemic tissue (Figure 3b-f). She felt a sense of extreme tiredness and discomfort. She continued the oral and topical therapies for 3 weeks without benefits; moreover, pruritus and generalized urticarial appeared on her face, especially on her ears (Figure 2c), so she decided to call the poison center of the "Azienda Ospedaliero-Universitaria, Ospedali Riuniti di Foggia" to ask medical aid. After an accurate evaluation of the reported symptoms, the physician recommended to go to the same hospital emergency room for an assessment of a probable spider bite and envenomation. Unfortunately, there is no single clinical laboratory test that can be used to diagnose a Loxosceles' bite. On October $10^{\text {th }}$, she was admitted in the infectious disease ward for 5 days, where she underwent to several medical tests to investigate on the cause of her skin ulceration, particularly if it could be associated to the spider's venom, or with another infectious or an autoimmune disease. Meanwhile, she developed an acute skin rash on her neck, on the trunk and the abdomen, and on the upper limbs. She was treated with prednisone tablets ( $25 \mathrm{mg} /$ day) for 5 days, lansoprazole tablets (30 mg/day), and Minocin (100 mg twice daily) for 10 days. The dermatologist also prescribed Bionect Start cream and "Connettivina" gauzes to medicate the

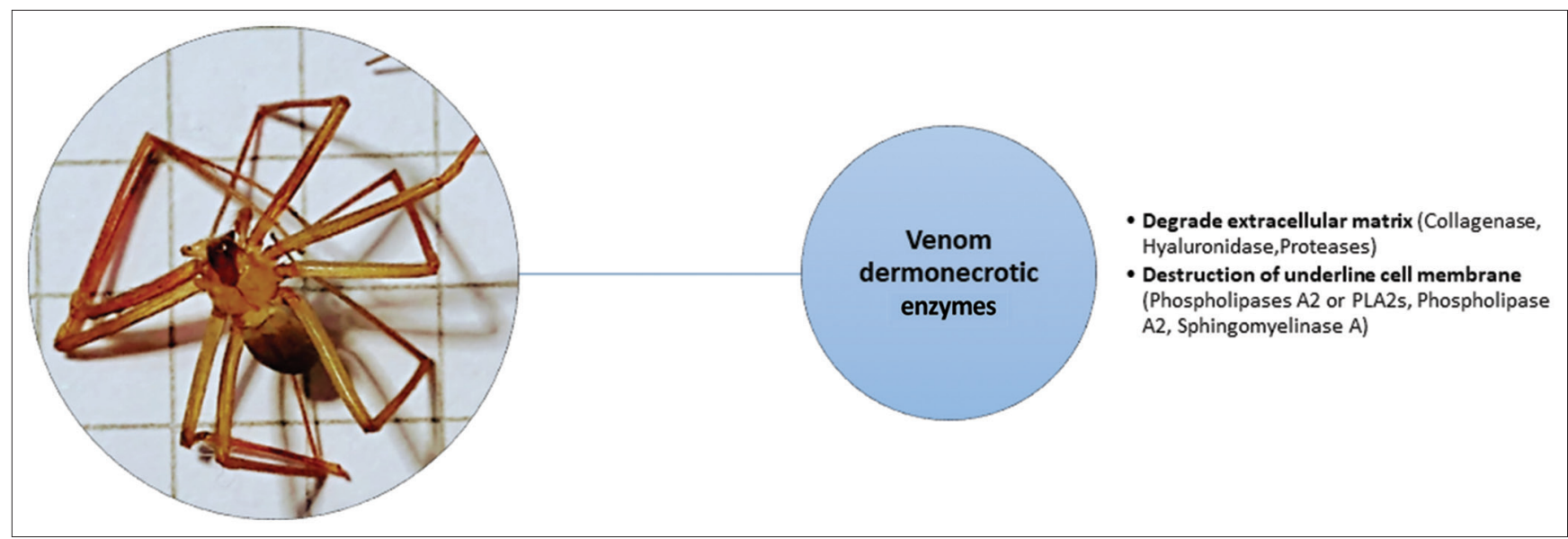

Figure 2: The "Mediterranean Recluse Spider" and its venom's enzymatic functions (spider not alive, photo by authors) 
lesion once daily for 10 days. During hospitalization, all the blood chemistry tests, bacteriological and virological laboratory tests resulted in the normal range. All tests for autoimmune diseases were negative.

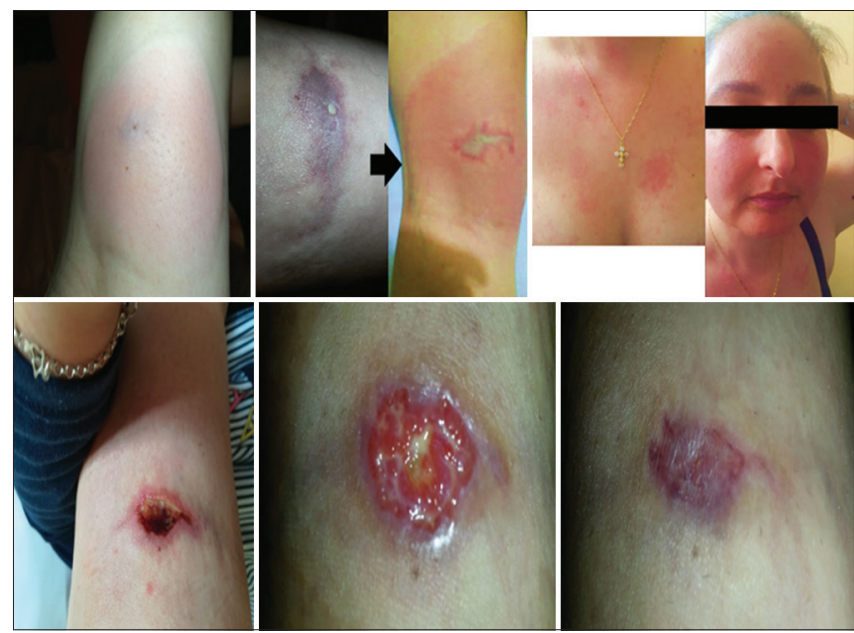

Figure 3: Clinical evolution of the spider bite on the right thigh and of the skin rash of the trunk

She was discharged after 5 days and she continued the home therapy with prednisone tablets ( $25 \mathrm{mg} /$ day) for 5 days and then 12,5 mg for others 5 days, lansoprazole tablets (30 mg/day) for 10 days, Minocin (100 mg twice daily) per 10 days, and Advantan cream + Bionect Start + Connettivina to medicate the lesion (she continued with the local therapy until December 2018 because the ulcer was not healed yet). She felt completely healed just in February 2019, when the sense of thickness and the pain on the leg finally disappeared. All the systemic and local treatments of this case are resumed in Figure 4.

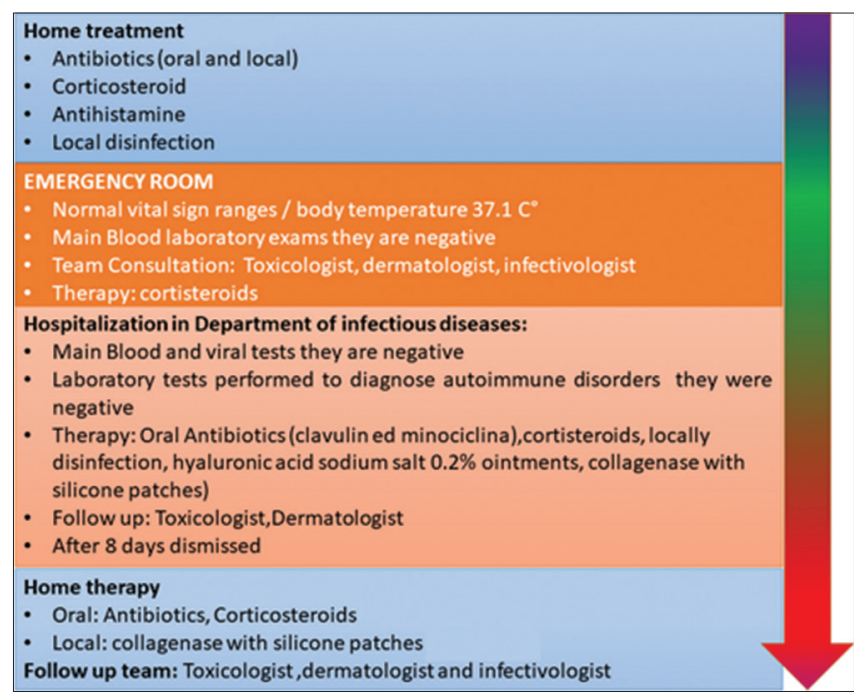

Figure 4: Resume of medical treatments of the reported case of presumed Loxosceles rufescens bite

\section{Discussion}

The case we report about this woman is probably due to a Loxosceles rufescens bite. To confirm a brown recluse spider bite, it is very important to collect the spider for exact identification, but only $10 \%$ of patients can do it because, as mentioned above, the bite is usually unnoticed. In these cases, diagnosis can be based on the patient's story, on skin's lesion appearance and other local and systemic manifestations, so, the diagnosis is often as presumptive of brown recluse spider bite. Despite loxoscelism can be associated with changes in laboratory values, including hemolysis, thrombocytopenia, coagulopathy, altered chemistry, and urinalysis results, she did not manifested these signs during the hospital stay; however, we cannot exclude the possibility that she developed them before consulting a specialist. The severity of clinical condition also depends on individual immune response and the amount of the injected venom: $90 \%$ of bites heal without complications and, in other $10 \%$, not every symptom or sign which characterized loxoscelism must be necessary be present. The presence of the skin lesion without other systemic parameters such as fever and negative blood tests do not exclude the hypothesis of brown recluse spider bite, but on the other hand, she might have developed them but without any laboratory test to demonstrate it [5], [16], [17].

The diagnosis, in the absence of spider identification, is based on epidemiology data (presence of the Loxosceles spider on the territory), medical history and clinical signs (skin manifestations, progressive painful solitary plaque with an ischemic necrotic central part surrounded by intense erythema), and unspecific manifestations such as fever, headache, and a generalized, itchy rash of measles or scarletlike type that appears in the first $24-48 \mathrm{~h}$ after the bite. In addition, diagnosis is supported by the exclusion of other possible causes of the same clinical picture (differential diagnosis in Table 1) [4], [7], [16].

In fact, this skin plaque and ulceration can be also associated to different medical conditions, including bacterial diseases (for example, Staphylococcus aureus, Staphylococcus epidermidis, anthrax, syphilis, and tularemia), viral infectious diseases (Herpes simplex and Herpes zoster), parasitosis (Lyme's disease, sporotrichosis, aspergillosis, and mucormycosis), skin cancer, vascular or diabetic ulceration, adverse drug skin reactions, traumatic skin injury, and autoimmunitary diseases such as the "pyoderma gangrenosum" [18], [19], [22], [23], [24], [25], [26].

The hematological, bacteriological, and virological laboratory results allow to exclude bacterial and fungal infections of the skin. The clinical evolution of the skin lesion, the development of the generalized symptomatology and the exclusion of other systemic diseases must differentiate diagnosis of a systemic envenomation. In these cases, is very helpful the consultation of other specialists such as a toxicologist, dermatologist and infectivologist. Some features of the skin lesion may be related to an insect bite, particularly a spider one [18], [27] (Figure 5). 
Table 1: The main differential diagnosis

\begin{tabular}{|c|c|c|c|c|c|c|c|c|}
\hline \multicolumn{9}{|c|}{ Main diseases for differential diagnosis } \\
\hline Bacteria & Virus & Fungi & $\begin{array}{l}\text { Lymphoproliferative } \\
\text { disorders }\end{array}$ & $\begin{array}{l}\text { Systemic diseases, } \\
\text { vasculitis }\end{array}$ & $\begin{array}{l}\text { Drug adverse } \\
\text { reactions }\end{array}$ & $\begin{array}{l}\text { Contact } \\
\text { dermatitis }\end{array}$ & $\begin{array}{l}\text { Diseases } \\
\text { transmitted by } \\
\text { arthropods }\end{array}$ & Miscellany \\
\hline $\begin{array}{l}\text { - Methicillin-resistant } \\
\text { staphylococcus } \\
\text { aureus } \\
\text { - Streptococcus } \\
\text { - Gonococcal } \\
\text { arthritis } \\
\text { - Anthrax } \\
\text { - Mycobacterium } \\
\text { ulcerans } \\
\text { - Syphilis } \\
\text { - Tularemia }\end{array}$ & $\begin{array}{c}\cdot \text { Herpes } \\
\text { simplex } \\
\cdot \text { Herpes } \\
\text { zoster }\end{array}$ & $\begin{array}{l}\text { - Sporotrichosis } \\
\text { - Aspergillosis } \\
\text { - Mucormycosis }\end{array}$ & $\begin{array}{l}\text { - Cutaneous T-cell } \\
\text { lymphoma }\end{array}$ & $\begin{array}{l}\text { - Vascular or diabetic ulcer } \\
\text { - Flesh-eating disease in } \\
\text { patients with liver disease } \\
\text { - Focal vasculitis } \\
\text { - Purpura fulminans } \\
\text { - Thromboembolism } \\
\text { - Polyarteritis nodosa } \\
\text { - Skin cancer }\end{array}$ & -Warfarin & $\begin{array}{l}\text { - Canadian Ivy } \\
\text { plant } \\
\text { - Poison oak } \\
\text { - Chemical } \\
\text { burns }\end{array}$ & $\begin{array}{l}\text { - Lyme disease } \\
\text { - Rocky Mountain } \\
\text { spotted fever } \\
\text { - Ornithodoros } \\
\text { coriaceus bite } \\
\text { - Insect bite }\end{array}$ & $\begin{array}{l}\text { - Pyoderma } \\
\text { gangrenosum } \\
\text { - Decubitus ulcer } \\
\text { - Stevens-Johnson } \\
\text { syndrome } \\
\text { - Erythema nodosum } \\
\text { - Toxic epidermal } \\
\text { necrolysis } \\
\text { - Lyell Syndrome }\end{array}$ \\
\hline
\end{tabular}

It is important asking help to an infectivologist because lots of skin lesions can be caused by the bites of non-venomous spiders, scorpions, bees, wasps, hornets, mosquitoes, and sand flies and they are quite indistinguishable from those of the brown spider. Finally, it is important the differential diagnosis between different species of insect that could cause this kind of skin lesions. Particularly, we must think about the most diffuse species of spiders which are present on the territory [22].

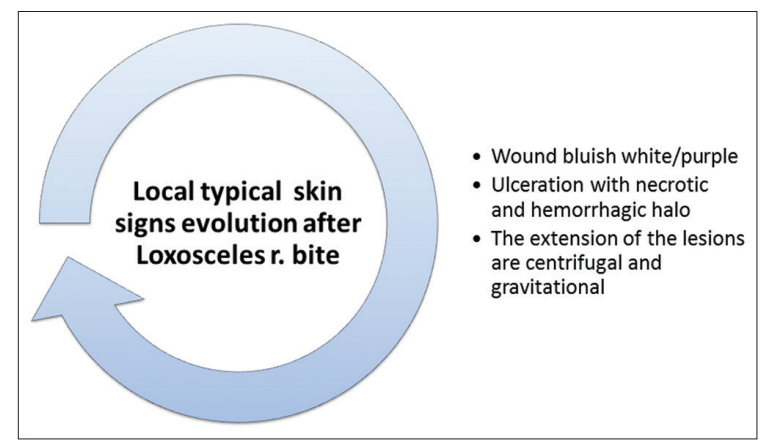

Figure 5: Typical skin lesion of Loxosceles rufescens bite

In Italy, in addition to the Loxosceles rufescens bite, other three types of spiders could give this kind of local and systemic reaction. The first one is the Segestria florentina, a spider which produces a neurotoxic venom; the Cheiracanthium punctorium which is a spider whose bite can be very painful, with a local reaction characterized by erythema, edema, and itchiness, while systemic symptoms are scarce; and Latrodectus tredecimguttatus (Mediterranean or European black widow) is mainly found in southern and central Italy along the Tyrrhenian coast, but also in Sardinia; patients bitten by this spider develop a mild to severe pain in the site of the bite, but also other systemic symptoms such as abdominal pain, chest pain, muscular contractures, and temporary psychomotor disabilities [27], [28], [29], [30], [31], [32], [33], [34].

Finally, we must mention that it is the first time that a possible case of systemic loxoscelism with skin generalized urticaria is reported in Italy.

\section{References}

1. Diaz HJ. The global epidemiology, syndromic classification, management, and prevention of spider bites. Am J Trop Med
Hyg. 2004;71(2):239-50.

PMid:15306718

2. World Spider Catalog. World Spider Catalog, Version 20. 5. Natural History Museum Bern; 2019. Available from: http://www. wsc.nmbe.ch. [Last accessed on 2019 Sep30]

3. Chaim OM, Trevisan-Silva D, Chaves-Moreira D, Wille AC Ferrer VP, Matsubara FH, et al. Brown spider (Loxosceles genus) venom toxins: Tools for biological purposes. Toxins (Basel). 2011;3(3):309-44. https://doi.org/10.3390/toxins3030309 PMid:22069711

4. Nentwig W. Ecophysiology of Spiders. Berlin: Springer Science, Business Media; 2012

5. Futrell J. Loxoscelism. Am J Med Sci. 1992;304:261-7. PMid:1415323

6. Atkin JA, Wingo CW, Sodeman WA, Flynn JE. Necrotic arachnidism. Am J Trop Med. 1958;7(2):165-84.

7. da Silva $\mathrm{PH}$, da Silveira RB, Appel MH, Mangili OC, Gremski W, Veiga SS. Brown spiders and loxoscelism. Toxicon. 2004;44(7):693-709. https://doi.org/10.1016/j. toxicon.2004.07.012

PMid: 15500846

8. Schenone H. Diagnosis in 1348 patients which consulted for a probable spider bite or insect sting. Bol Chil Parasitol. 1996;51:20-7.

PMid:9196950

9. Sezerino UM, Zannin M, Coelho LK, Gonçalves J, Grando M, Mattosinho SG, et al. A clinical and epidemiological study of Loxosceles spider envenoming in Santa Catarina, Brazil. Trans R Soc Trop Med Hyg. 1998;92(5):546-8. https://doi.org/10.1016/ s0035-9203(98)90909-9

PMid:9861376

10. da Silveira RB, dos Santos Filho JF, Mangili OC, Veiga SS, GremskiW, Nader HB, etal. Identification of proteases in the extract of venom glands from brown spiders. Toxicon. 2002;40(6):81522. https://doi.org/10.1016/s0041-0101(02)00078-8

PMid: 12175619

11. Veiga SS, da Silveira RB, Dreyfus JL, Haoach J, Pereira AM, Mangili OC, et al. Identification of high molecular weight serine-proteases in Loxosceles intermedia (brown spider) venom. Toxicon. 2000;38(6):825-39. https://doi.org/10.1016/ s0041-0101(99)00197-x PMid:10695968

12. Appel MH, da Silveira RB, Gremski W, Veiga SS. Insights into brown spider and loxoscelism. Invertebr Surviv J. 2005;2(2):152-8.

13. Rubenstein E, Stoebner PE, Herlin C, Lechiche C, Rollard C Laureillard D, et al. Documented cutaneous loxoscelism in the South of France: An unrecognized condition causing delay in diagnosis. Infection. 2016;44:383-7. https://doi.org/10.1007/ s15010-015-0869-4

PMid:26744020 
14. Hubiche T, Delaunay P, del Giudice P. A case of loxoscelism in Southern France. Am J Trop Med Hyg. 2013;88:807-8. https:// doi.org/10.4269/ajtmh.12-0339

15. Dandria D, Mahoney P. First record of spider poisoning in the Maltese Islands. Cent Mediterr Nat. 2002;3:173-6.

16. Hubbard JJ, James LP. Complications and outcomes of brown recluse spider bites in children. Clin Pediatr (Phila). 2011;50(3):252-8. https://doi.org/10.1177/0009922810388510 PMid:21307081

17. Thompson AL. Laboratory testing in monitoring the effects of brown recluse spider bites. Lab Med. 2013;44(4):300-3. https:// doi.org/10.1309//mkiw3wioo13emmm

18. Swanson DL, Vetter RS. Bites of brown recluse spiders and suspected necrotic arachnidism. N Engl J Med. 2005;352(7):7007. https://doi.org/10.1056/nejmra041184 PMid: 15716564

19. Ribuffo D, Serratore F, Famiglietti M, Greco M, Fois F, Atzori L, et al. Upper eyelid necrosis and reconstruction after spider byte: Case report and review of the literature. Eur Rev Med Pharmacol Sci. 2012;16(3):414-7.

PMid:22530360

20. Coutinho I, Rocha S, Ferreira ME, Vieira R, Cordeiro MR, Reis JP. Cutaneous loxoscelism in Portugal: A rare cause of dermonecrosis. Acta Med Port. 2014;27(5):654-7. https://doi. org/10.20344/amp.4891 PMid:25409224

21. Yigit $\mathrm{N}$, Bayram A, Ulasoglu D, Danisman $\mathrm{T}$, Ocal $\mathrm{Cl}$, Sancak Z. Loxosceles spider bite in Turkey (Loxosceles rufescens, Sicariidae, Araneae). J Venom Anim Toxins Incl Trop Dis. 2008;14(1):178-87. https://doi.org/10.1590/ s1678-91992008000100016

22. Bhatti AZ, Adeniran A, Salam S, Naveed MA, Phillips A. Brown recluse spider bite to the leg. Inj Extra. 2006;37:45-8. https://doi. org/10.1016/j.injury.2005.07.009

23. Giudice G, Cutrignelli DA, Sportelli P, Limongelli L, Tempesta A, Gioia GD, et al. Rhinocerebral mucormycosis with orosinusal involvement: Diagnostic and surgical treatment guidelines. Endocr Metab Immune Disord Drug Targets. 2016;16(4):264-9. https://doi.org/10.2174/1871530316666161223145055 PMid:28017141

24. Di Serio F, Lovero R, D’Agostino D, Nisi L, Miragliotta G, Contino R, et al. Evaluation of procalcitonin, Vitamin D and C-reactive protein levels in septic patients with positive emocoltures. Our preliminary experience. Acta Med Mediterr. 2016;32:1911-4.

25. Prejbeanu R, Vermesan H, Dragulescu SI, Vermesan D, Motoc $A$, Sabatini $R$, et al. Thromboembolic risk after knee endoprosthesis.
Eur Rev Med Pharmacol Sci. 2007;11(5):297-300. PMID: 18074938.

26. Vermesan D, Vermesan $H$, Dragulescu SI, Bera I, Di Giovanni A, Sabatini R, et al. Secondary pathologic fractures in osteosarcoma: Prognosis and evolution. Eur Rev Med Pharmacol Sci. 2009;13(2):71-6.

PMid: 19499840

27. Nentwig W, Pantini P, Vetter RS. Distribution and medical aspects of Loxosceles rufescens, one of the most invasive spiders of the world (Araneae: Sicariidae). Toxicon. 2017;132:19-28. https:// doi.org/10.1016/j.toxicon.2017.04.007

PMid:28408204

28. Planas E, Zobel-Thropp PA, Ribera C, Binford G. Not as docile as it looks? Loxosceles venom variation and loxoscelism in the Mediterranean Basin and the Canary Islands. Toxicon. 2015;93:11-9. https://doi.org/10.1016/j.toxicon.2014.10.005 PMid:25449105

29. StefanidouMP,ChatzakiM,LasithiotakisKG, IoannidouDJ,ToscaAD, Necrotic arachnidism from Loxosceles rufescens harboured in Crete, Greece. J Eur Acad Dermatol Venereol. 2006;20(4):486-7. https://doi.org/10.1111/j.1468-3083.2006.01486.x PMid:16643168

30. Cohen N, Sarafian DA, Alon I, Gorelik O, Zaidenstein R, Simantov $\mathrm{R}$, et al. Dermonecrotic loxoscelism in the Mediterranean region. J Toxicol Cutan Ocul Toxicol. 1999;18(1):75-83. https://doi.org/10.3109/15569529909049325

31. Swanson DL, Vetter RS. Loxoscelism. Clin Dermatol. 2006;24(3):213-21.

PMid: 16714202

32. Gremski LH, Trevisan-Silva D, Ferrer VP, Matsubara FH, Meissner GO, Wille AC, et al. Recent advances in the understanding of brown spider venoms: From the biology of spiders to the molecular mechanisms of toxins. Toxicon. 2014;83:91-120. https://doi.org/10.1016/j.toxicon.2014.02.023 PMid:24631373

33. Dyachenko P, Ziv M, Rozenman D. Epidemiological and clinical manifestations of patients hospitalized with brown recluse spider bite. J Eur Acad Dermatol Venereol. 2006;20:1121-5. https://doi. org/10.1111/j.1468-3083.2006.01749.x PMid:16987269

34. Andersen RJ, Campoli J, Johar SK, Schumacher KA, Allison EJ Jr. Suspected brown recluse envenomation: A case report and review of different treatment modalities. J Emerg Med. 2011;41:e31-7. https://doi.org/10.1016/j.jemermed.2009.08.055 PMid:20363581 